\title{
Students' Perceptions of Teachers' Power in High School, University, and English Language Institute
}

\author{
Nader Assadi Aidinlou ${ }^{1} \&$ Roya Jafari Amineh ${ }^{2}$ \\ ${ }^{1}$ Ph.D. in Applied Linguistics, President of Islamic Azad University, Ahar Branch, Iran \\ ${ }^{2} \mathrm{Ph} . \mathrm{D}$. Candidate in TEFL, Department of English Language and Literature, Islamic Azad University, Ahar \\ Branch, Iran \\ Correspondence: Roya Jafari Amineh, Department of English Language and Literature, Islamic Azad University, \\ Ahar Branch, Ahar, Iran. E-mail: royajafari25@gmail.com
}

Received: August 17, 2016 Accepted: September 10, 2016 Online Published: November 23, 2016

doi:10.5539/ijel.v6n6p76 URL: http://dx.doi.org/10.5539/ijel.v6n6p76

\begin{abstract}
The primary focus of this study is to determine and compare Iranian students' perceptions of their English teachers' power in high schools, universities, and English language institutes. The research employed French \& Raven's (1959) framework of relational power bases (i.e., coercive, reward, expert, legitimate, and referent power) for understanding teachers' power in this classroom. To this end, Teacher Power Use Scale (TPUS, Schrodt, Witt, \& Turman, 2007) was translated to Persian and piloted among 150 students in all three educational contexts. After estimating reliability of Persian adaptation in the pilot study, 450 volunteer students responded to TPUS in the main study. For reliability studies, Cronbach Alpha and for validity studies, exploratory factor analysis were estimated.

Also, this study aimed to find out whether there are any other kinds of teachers' power in educational contexts except what were represented by French \& Raven's (1959). For this purpose, the study used observation and interview.

The final results basically supported both French \& Raven's (1959) framework of relational power and also the original TPUS. Further, the findings suggested students' perception of other kinds of teachers' power beyond what was represented in the previous researches.
\end{abstract}

Keywords: discourse, students' perceptions, French \& Rave's (1959) power bases, teachers' power, TPUS

\section{Introduction}

Discourse and language equation was proposed by people who are specifically interested in language and language acquisition. Language has been defined as a system of arbitrary symbols that are used for human communication. On the other hand, discourse analysis refers to the study of the language of communication-spoken or written (Hatch, 1992). From this mentioned perspective, Fairclough (1989) - as one of the founders of critical discourse analysis- equated the concept of language with discourse and noted that the way that language is used is not neutral or apolitical. Instead, speakers and writers ground the use of language in a set of beliefs, or what Fairclough terms ideologies.

Hence, power seems to be an important element of any discourse, and language is entwined in social power in a number of different ways. This means that language indexes power, expresses power, and even challenges power (Wodak \& Meyer, 2015). According to French \& Raven (1959), social power highlight "the resources one person has available so that he or she can influence another person to do what that person would not have done otherwise." Further, Quicke (1999) added that it is imperative for education professionals to critically examine the "role of power in the construction" of themselves as professionals and "their stance towards their own expertise" (p. 51).Thus, the educational paradigm emphasized the articulation of power in the classroom (Jackman, 2014).

Teachers' power in its own is also vital and can be considered as the foundation upon which to professionalize teaching (Maxcy, 1991). In other words, power is inherent in promoting change and learning. Since education is a process of change, teachers become the main agents of that change in students. Most of the times, teachers impinge on students -sometimes subtly, sometimes strongly. Teachers also challenge students. While this process 
of students' change may be uncomfortable and threatening for students, the process of education almost always includes his change and the teachers exercise power over students in some way (Fisch, 1992). However, there are various forms of teachers' power. Initially, teachers' power simply highlighted teachers' academic demands that students had to obey without any objection (Peters, 1966; Metz, 1978; Kearney, Plax, Richmond, \& McCroskey, 1984; Franklin, 1986). Richmond \& McCroskey (1984) defined teacher power as teachers' capacity to affect students to do what they would not have done if they had not been influenced and forced by the teacher. Raywid (1995) cited that Teacher's power is extremely impressive with regard to creating and controlling the social environment of the classroom. Teacher must determine the roles and expectations of every person in the classroom. Also, teachers are responsible to arrange classroom activities and at the same time decide about general tone of the classroom as relaxed and informative, supportive and friendly, cooperative, and etc.

On the other hand, MacBeath \& Mortimore (2001) pointed out that learners' beliefs and ideas should not be neglected in the classrooms. They reminded that learners' perceptions are better to be considered as good sources of information to teachers. Barkhuizen (1998) reminded that learners should be encouraged to express their perceptions and ideas overtly, both for themselves and also for their teachers. Kumaravadivelu (1991) confirmed and encouraged asking learners' personal approaches and views. Moreover, the use of specific power bases (i.e., reference and expert power) is positively correlated with student's cognitive and affective learning (Richmond \& McCroskey, 1984).

Thus it can be concluded that once teachers become aware of their students' perceptions in educational system, they can plan and devise alternative behaviors and activities that are needed in their classes (Shahini \& Daftarifard, 2010).

\subsection{Purpose}

The primary goal of this study is to determine Iranian students' perceptions of their English teachers' power in three contexts of high school, university, and English language institutes based on French \& Raven's (1959) framework of relational power in the classroom. Also, the study seeks to find out whether there are any other kinds of teachers' power based on Iranian students' perceptions except what were represented by French \& Raven's (1959).

\section{Review of Literature}

A central notion in most critical work on discourse is that of power, and more specifically the social power of groups or institutions. Summarizing a complex philosophical and social analysis, social power is explained in terms of control. Thus, groups have (more or less) power if they are able to (more or less) control the acts and minds of (members of) other groups. This ability presupposes a power base of privileged access to scarce social resources, such as force, money, status, fame, knowledge, information, "culture," or indeed various forms of public discourse and communication (Vandijk, 2001).

Since the early 1980s, the study of power in the classroom has received a great amount of attention and most of the early researches were informed by French \& Raven's (1959) typology of social power as a relational phenomenon bases. French and Raven's power bases include coercive power (the threat of administering punishing consequences or the removal of rewarding ones), legitimate power (based on the power one has been assigned by an individual or an organization), reward power (the use of positive consequences or removal of negative ones), referent power (which is based on good relationships and identification with those in power), and expert power (related to perceptions of one's knowledge and ability in a given area).

Also, French \& Raven (1959) stated that the primary purpose of identifying the five power bases was to permit observation of "the changes which they produce and the other effects which accompany the use of power" (p. 150).

Although French \& Raven (1959) had not written about power in classroom as their intended focus, McCroskey \& Richmond (1983) examined and redefined those kinds of power-as written below- based on teachers' power in the classroom context.

Coercive power. A teacher's coercive power indicates that students expect to be punished by the teacher when they do not conform to the teacher's influence and desire. The strength of the teacher's coercive power depends on the student's perception of how probable it is that the teacher will punish him/her for non-conformance. So, the teacher's coercive power is contingent upon the degree of negative result such punishment would entail, minus the probable punishment from other sources like peers. It is worth to mention here that where competitions among students and so strong peer-group pressure against the teacher exist, the teacher seem not to have coercive power at all, although the teacher may have the ability to exert a high degree of punishment. 
Reward power. A teacher's reward power is based on student's perception of how and how much the teacher provides reward to her/him for complying with the teacher's influence. Such rewards may include providing something positive (positive reinforcement) or removing something negative (negative reinforcement). Similar to coercive power, the strength of a teacher's reward power is mediated by probability of receiving other rewards from other sources as a function of non-compliance.

Although the relationship between coercive and reward power is often not recognized, these two kinds of power are essentially the flip sides of the same coin. Coercive power involves introducing something unpleasant or removing something pleasant when the student cannot comply. Reward power involves introducing something pleasant or removing something unpleasant if the student does comply.

Legitimate power. Legitimate power, often referred to as assigned power, stems from the assigned role of the teacher in the classroom. Legitimate power is based on the student's perception that the teacher can make certain demands and requests as a function of her/his position as teacher. This power generally is most related to worldly matters like controlling classroom time, determining what unit should be studied, and regulating interaction. Legitimate power generally does not extend beyond the school environment in to the private lives of students. In some cases, however, this type of power is much broader. For instance, when a coach sets up training rules. These rules are considered legitimate demands from the person with the role of coach, and so the athletes usually follow all of the rules.

Referent Power. Referent power has its origins in how the student's identification with the teacher. This power is clear in the relationship between two people. Specifically, Referent power sheds light on the desire of the less powerful person (the student) to be identified and satisfied with the more powerful person (teacher). The stronger student's identification with teacher leads to the stronger teacher's referent power.

Expert Power. Expert power exists when the student perceives that the teacher is competent and knowledgeable in specific areas. Most information taught in a classroom is presented from an expert power. The ideas are not "proven" objectively. Instead, the ideas are presented with the expectation that they will be accepted by the student. This expectation will be correct till student sees the teacher as competent and knowledgeable. French \& Raven (1968) emphasize that the main impact of expert power is change in an individual's cognitions. Any change in behavior is the second result of that influence.

These five kinds of powers can be combined and are often exercised differently within education in order to yield order in the classroom (Smith \& Hains, 2012). For example, power in adult education is usually derived from expertise and reward powers. The reason is that adults believe the professor has a superior expertise in a given field of study, as well as the ability to judge their performance in his classroom (Johnson-Bailey \& Cervero, 1997).

Additionally, McCroskey \& Richmond (1983) remarked that the type and the extent of teacher power depend to a large extent on the ways teachers communicate with their students, while the same researchers said that teacher power exists if students believe it exists and accept it (Richmond \& McCroskey, 1984). This acceptance was described by van Manen (1991) as a necessary element of teacher power which is granted by the child, first based on his/her trust and love, and later on the basis of critical understanding. Harjunen (2011) further confirmed that teacher power is based on interactions between teacher and students in the classroom where enduring tension between positive and negative aspects of teacher power is displayed. She also reported that teachers who effectively exert their power look for ways to get students to participate in the teaching-studying-learning process' (Harjunen, 2011).

According to what was mentioned, teachers' power has different forms. The best kind of teachers' power seems to occur when an educator can exercised his or her power to support children's holistic physical, mental, and morel development (Huebner et al., 2009); whereas the worst kind of teachers' power is exercised when teachers humiliate and ridicule some students in front of others and leave negative impressions about themselves in students' minds (Johnson, 1997 \& Walls et al., 2001).

Overall, a certain and appropriate degree of teacher' power needs to be always present in the classrooms (Hurt et al., 1978). However, a number of investigators unfortunately have exerted their whole power and ignored their students' roles in the educational system (Miles, 1967; Chesler \& Franklin, 1968; Chesler \& Lohman, 1971). Hence, such teachers just consider students as clients of the education rather than as its members.

Consequently, the students and their perceptions in educational systems should be given more attention and teachers need to use their power wisely and appropriately in all classes. 


\section{Method}

\subsection{Participants}

The sample in this study included 450 Iranian students who studied English in three different educations contexts. The first group of participants involved 150 students from two different high Schools (third year), the second group were150 students from two universities (the first year), and the last group were 150students form 3 English Language Institutes (intermediate level). Student participation was voluntary in this research and the participants ranged between 17 and 22. Also the participants in each group were 225 male and 225 female students.

\subsection{Instruments and Design}

Teacher Power Use Scale (TPUS). To measure students' perceptions of teachers' power use, TPUS — originally developed by Schrodt, Witt, \& Turman (2007) was used in this research. The TPUS is a 30-item, Likert-type scale that asks students to evaluate the extent to which their teacher uses five types of relational power in the classroom. This questionnaire asks about each type of power through examples related to the classroom. Instances of TPUS items include "My teacher punishes students who do not follow his/her constructions." for coercive power, "My teacher rewards the class for complying with his/her requests." for reward power, "My teacher builds rapport with the class by relating to students in an open and approachable manner." for referent power, "My teacher relates to students in ways that are formal and distant." for legitimate power, and "My teacher communicates in ways that demonstrate advanced knowledge/expertise in the content area of the course." for expert power. Responses of TPUS include a 7-point scale that ranges from (1) Never to (7) Always. Schrodt et al. (2008) noted that recent research had supported the construct validity and reliability of the TPUS.

Also for qualitative analysis, the research used observation and interview. The researcher used semi-structured interviews in which the students were supposed to represent the evidences and reasons of their responses to TPUS. Further, the researcher asked students about any other kinds of teachers' power which were not measured by TPUS.

Additionally, the researcher observed all classes for four months and used note-taking, checklists, and recorded the discourses between teachers and students in order to find out students' perceptions of different kinds of teachers' power.

This study followed a mixed method design in order to achieve a fuller understanding of students' perceptions of teachers' power in high schools, universities and English language institutes. Data were collected based on students' responses to TPUS, results of interviews and observations. Then, findings were studied and compared among high schools, universities, and English language institutes.

\subsection{Procedures}

Since the scale (TPUS) was originally developed in English, the researcher first translated the questionnaire to Persian. The adequacy and fluency of translation of all items were checked by 10 university professors of TEFL in Iranian universities. Then, pilot study was conducted in order to investigate the reliability of the scale. The data were gathered from a total number of 150 Iranian students -50students in high schools, 50 students in universities, and 50 students in English Language Institutes. For reliability studies, Cronbach Alpha was estimated, but because of low reliability, the items were rechecked. With removal of item 22, Alpha Cronbach reliability ranged 0.719 for 29 items.

Table 1. Reliability statistics

\begin{tabular}{ll}
\hline Cronbach's Alpha & N of Items \\
\hline 719 & 29 \\
\hline
\end{tabular}

Then, the questionnaires were distributed among 450 volunteer students -150 from high schools, 150 from universities, and 150 from English language institutes in the main study. After collecting data, the researcher estimated Cronbach Alpha reliability which was 862 according to the following table.

Table 2. Reliability Statistics

\begin{tabular}{ll}
\hline Cronbach's Alpha & N of Items \\
\hline 862 & 29 \\
\hline
\end{tabular}


For validity studies of translated TPUS, the researcher used KMO and Bartlett's test of sphericity in order to check the adequacy of using factor analysis for the questionnaire. In other words, KMO and Bartlett's test of sphericity check if there is a certain redundancy between the variables that we can summarize with a few numbers of factors. As shown in the table below, KMO was greater than 0.7 and sig of Bartlett's test of sphericity was below 0.01.Thus, the researcher used factor analysis in this study (Table 4.).

Table 3. KMO and bartlett's test

\begin{tabular}{lll}
\hline Kaiser-Meyer-Olkin Measure of Sampling Adequacy. & 0.837 \\
\hline & Approx. Chi-Square & 2097.452 \\
\multirow{3}{*}{ Bartlett's Test of Sphericity } & df & 406 \\
& Sig. & 0 \\
\hline
\end{tabular}

Table 4. Means, standard deviations, communalities, factor loadings and item-total correlation coefficients

\begin{tabular}{|c|c|c|c|c|c|c|c|c|c|}
\hline \multirow[t]{2}{*}{ Item no } & \multirow[t]{2}{*}{ Mean } & \multirow{2}{*}{$\begin{array}{l}\text { Std. } \\
\text { Deviation }\end{array}$} & \multirow[t]{2}{*}{ Communalities } & Factor1 & Factor2 & Factor3 & Factor4 & Factor5 & \multirow{2}{*}{$\begin{array}{l}\text { Item-total } \\
\text { correlation }\end{array}$} \\
\hline & & & & Expert & Coercive & Reward & Referent & Legitimate & \\
\hline 25 & 5.2411 & 1.64274 & .507 & 0.702 & & & & & .853 \\
\hline 26 & 4.0496 & 1.63588 & .232 & 0.462 & & & & & .857 \\
\hline 27 & 5.6241 & 1.45179 & .669 & 0.773 & & & & & .851 \\
\hline 28 & 5.2695 & 1.59857 & .695 & 0.785 & & & & & .851 \\
\hline 29 & 5.4894 & 1.59740 & .702 & 0.746 & & & & & .851 \\
\hline 30 & 5.3191 & 1.63147 & .621 & 0.720 & & & & & .851 \\
\hline 1 & 5.7305 & 1.54402 & .510 & & -.683 & & & & .856 \\
\hline 2 & 5.9220 & 1.50746 & .638 & & -.740 & & & & .855 \\
\hline 3 & 5.9858 & 2.68324 & .247 & & -.360 & & & & .869 \\
\hline 4 & 5.9645 & 1.40108 & .484 & & -.629 & & & & .858 \\
\hline 5 & 4.6383 & 1.96860 & .579 & & -.743 & & & & .856 \\
\hline 6 & 4.0780 & 1.81293 & .375 & & -.471 & & & & .867 \\
\hline 7 & 4.0638 & 2.12540 & .581 & & & .567 & & & .853 \\
\hline 8 & 5.7730 & 1.38548 & .547 & & & .545 & & & .856 \\
\hline 9 & 4.4752 & 1.79913 & .598 & & & .713 & & & .861 \\
\hline 10 & 4.3121 & 1.83278 & .596 & & & .329 & & & .859 \\
\hline 11 & 4.1277 & 1.76413 & .532 & & & .412 & & & .857 \\
\hline 12 & 4.5603 & 1.72117 & .509 & & & .464 & & & .856 \\
\hline 13 & 5.5745 & 1.43045 & .548 & & & & .667 & & .855 \\
\hline 14 & 3.5816 & 1.98262 & .533 & & & & .541 & & .853 \\
\hline 15 & 4.7660 & 1.74290 & .374 & & & & .596 & & .854 \\
\hline 16 & 3.5745 & 1.93920 & .475 & & & & .587 & & .853 \\
\hline 17 & 3.5248 & 1.68006 & .633 & & & & .555 & & .853 \\
\hline 18 & 3.2837 & 1.70011 & .513 & & & & .415 & & .857 \\
\hline 19 & 5.3050 & 1.96375 & .580 & & & & & -.610 & .856 \\
\hline 20 & 5.1986 & 1.94283 & .737 & & & & & -.610 & .856 \\
\hline 21 & 3.4894 & 1.97707 & .647 & & & & & .469 & .874 \\
\hline 23 & 1.7943 & 1.52371 & .531 & & & & & .711 & .870 \\
\hline 24 & 2.1135 & 1.90147 & .317 & & & & & .382 & .874 \\
\hline
\end{tabular}

In addition to TPUS, the researcher interviewed with students. The researcher interviewed with 60 voluntary participants-20 students from each educational context- about any other kind of teacher's power in addition to what they saw and responded in TPUS questionnaire. Actually, the researcher used semi-structured interviews - when asking about other kinds of power besides what was mentioned in TPUS-(cited in Dornyei, 2010). Also, the researcher tried to keep interval time between responding to TPUS and interviewing as short as possible- about two hours-after the students completed TPUS questionnaire. All interviews took about 10-15 minutes and all the interviewees were encouraged to say the evidences and reasons for what they said-either rejecting any other kind of teachers' power besides French \& Raven's (1959) relational power or accepting it. In 
this part of the research, the phenomenological design was used. According to Welman \& Kruger (1999, p. 189), "the phenomenologists are concerned with understanding social and psychological phenomena from the perspectives of people involved". Thus, the researcher tried to find out Iranian students' perceptions of other kinds of their English teachers' power except what were introduced in French \& Raven's (1989) framework of relational power.

Besides TPUS and interviews, the researcher used observation technique and observed all the classes in high schools, universities, and English language institutes. As cited in Best \& Kahn (2006), the presence of an outside observer over a period of time will be viewed as part of natural setting and so reduces the possible reactive effect more efficiently. Hence, the researcher observed the classes for two months. To achieve content validity of observations, the researcher identified certain aspects of teachers' power based on French \& Raven's power bases (1959) in advance and tried to find related evidence based on those types of teachers' power. Like interviews, the researcher looked for other kinds of teachers' power that had not been represented by French and Raven's power typology (1959).

For reliability of observation, the researcher repeated observing the classes and comparing the results of each observation with others' for four months; so that the errors in interpretation of teacher's power and the probability of missing the evidences of teachers' power be reduced.

\section{Results}

For reliability studies of 450 students, Cronbach Alpha was estimated (see table 2). Also, KMO and Bartlett's Test, and factor analysis of 450 students were estimated before factor analysis studies. As KMO (see Table 3) was above. 7, conducting factor analysis was possible in this research. There were 5 factors involved in factor analysis, Expert power, Coercive power, reward power, referent power, legitimate power respectively (see Table4.). Also, descriptive statistics of all factors among high schools, universities, and English language institutes are reported in table 5. Factor 1, Expert power, demonstrated greatest mean in the university, 5.7804, and the least mean, 4.6422, in the school. On the other hand, factor5, legitimate power, had the greatest mean, 3.0667 , in school and the least mean, 2.2681, in the institute.

Table 5. Descriptives

\begin{tabular}{llllll}
\hline & & $\mathrm{N}$ & Mean & Std. Deviation & Std. Error \\
\hline fac.1 & School & 150 & 4.6422 & 1.17318 & .09579 \\
Expert power & amozeshgah & 142 & 5.4671 & .82758 & .06945 \\
& Uni & 148 & 5.7804 & .88705 & .07292 \\
& Total & 440 & 5.2913 & 1.08867 & .05190 \\
\hline fac.2 & School & 150 & 3.4844 & 1.20330 & .09825 \\
Coercive power & amozeshgah & 150 & 2.1644 & .94852 & .07745 \\
& Uni & 150 & 2.2856 & .60950 & .04977 \\
& Total & 450 & 2.6448 & 1.12163 & .05287 \\
\hline fac.3 & School & 146 & 4.2934 & 1.28151 & .10606 \\
Reward power & amozeshgah & 148 & 4.8457 & .96286 & .07915 \\
& Uni & 150 & 5.1800 & 1.05736 & .08633 \\
& Total & 444 & 4.7770 & 1.16398 & .05524 \\
\hline fac. 4 & School & 150 & 3.5378 & 1.24694 & .10181 \\
Referent power & amozeshgah & 149 & 4.3356 & .91615 & .07505 \\
& Uni & 149 & 4.3893 & .97849 & .08016 \\
& Total & 448 & 4.0863 & 1.12493 & .05315 \\
\hline fac. 5 & School & 150 & 3.0667 & 1.30413 & .10648 \\
Legitimate power & amozeshgah & 144 & 2.2681 & .90844 & .07570 \\
& Uni & 150 & 2.3160 & 1.16095 & .09479 \\
& Total & 444 & 2.5541 & 1.19436 & .05668 \\
\hline
\end{tabular}

The researcher also used one-way Anova (Table 6) research in order to see whether there are significant different between groups for all factors. As sig was below 0.05 , the researcher found there are significant differences between groups for all five factors - five kinds of power. 
Table 6. ANOVA

\begin{tabular}{lllllll}
\hline & & Sum of Squares & Df & Mean Square & F & Sig. \\
\hline fac. 1 & Between Groups & 102.991 & 2 & 51.495 & 53.925 & .000 \\
& Within Groups & 417.315 & 437 & .955 & & \\
& Total & 520.305 & 439 & & 78.110 & .000 \\
\hline fac. 2 & Between Groups & 159.720 & 2 & 79.860 & & \\
& Within Groups & 405.148 & 447 & .906 & & .000 \\
& Total & 564.868 & 449 & & 24.132 & \\
\hline fac. 3 & Between Groups & 59.208 & 2 & 29.604 & & .000 \\
& Within Groups & 540.995 & 441 & 1.227 & 30.436 & \\
& Total & 600.203 & 443 & & & .000 \\
\hline fac. 4 & Between Groups & 68.066 & 2 & 34.033 & & \\
& Within Groups & 497.597 & 445 & 1.118 & & \\
& Total & 565.663 & 447 & & & \\
\hline fac. 5 & Between Groups & 59.695 & 2 & 29.847 & & \\
& Within Groups & 572.248 & 441 & & & \\
& Total & 631.943 & 443 & & & \\
\hline
\end{tabular}

Then the researcher used post hoc tests in order to confirm where the differences occurred between groups (Table 7).The findings showed that for factors 1-expert power-, 3-reward power-, and 4-referent power-; mean scores of school is less than those of university and English language institute while for factors 2-coercive power- and 5- legitimate power-; mean scores of school is more than those of university and English language institute.

Table 7. Tukey's HSD

\begin{tabular}{|c|c|c|c|c|c|c|}
\hline \multicolumn{2}{|c|}{ Dependent Variable } & (I) group & $(\mathrm{J})$ group & Mean Difference (I-J) & Std. Error & Sig. \\
\hline \multirow{30}{*}{ dimension 1} & \multirow[t]{6}{*}{ fac. 1} & School & Amozeshgah & $-.82491^{*}$ & .11442 & .000 \\
\hline & & & Uni & $-1.13818^{*}$ & .11322 & .000 \\
\hline & & Amozeshgah & school & $.82491^{*}$ & .11442 & .000 \\
\hline & & & Uni & $-.31327^{*}$ & .11479 & .025 \\
\hline & & Uni & school & $1.13818^{*}$ & .11322 & .000 \\
\hline & & & amozeshgah & $.31327^{*}$ & .11479 & .025 \\
\hline & \multirow[t]{6}{*}{ fac. 2} & School & amozeshgah & $1.32000^{*}$ & .10993 & .000 \\
\hline & & & Uni & $1.19889^{*}$ & .10993 & .000 \\
\hline & & Amozeshgah & school & $-1.32000^{*}$ & .10993 & .000 \\
\hline & & & Uni & -.12111 & .10993 & .546 \\
\hline & & Uni & school & $-1.19889^{*}$ & .10993 & .000 \\
\hline & & & amozeshgah & .12111 & .10993 & .546 \\
\hline & \multirow[t]{6}{*}{ fac. 3} & School & amozeshgah & $-.55234^{*}$ & .12919 & .000 \\
\hline & & & Uni & $-.88662^{*}$ & .12877 & .000 \\
\hline & & Amozeshgah & school & $.55234^{*}$ & .12919 & .000 \\
\hline & & & Uni & $-.33428^{*}$ & .12832 & .034 \\
\hline & & Uni & school & $.88662^{*}$ & .12877 & .000 \\
\hline & & & amozeshgah & $.33428^{*}$ & .12832 & .034 \\
\hline & \multirow[t]{6}{*}{ fac. 4} & School & amozeshgah & $-.79779^{*}$ & .12231 & .000 \\
\hline & & & Uni & $-.85148^{*}$ & .12231 & .000 \\
\hline & & Amozeshgah & school & $.79779^{*}$ & .12231 & .000 \\
\hline & & & Uni & -.05369 & .12251 & .908 \\
\hline & & Uni & school & $.85148^{*}$ & .12231 & .000 \\
\hline & & & amozeshgah & .05369 & .12251 & .908 \\
\hline & \multirow[t]{6}{*}{ fac. 5} & School & amozeshgah & $.79861^{*}$ & .13290 & .000 \\
\hline & & & Uni & $.75067^{*}$ & .13154 & .000 \\
\hline & & Amozeshgah & school & $-.79861^{*}$ & .13290 & .000 \\
\hline & & & Uni & -.04794 & .13290 & .937 \\
\hline & & Uni & School & $-.75067^{*}$ & .13154 & .000 \\
\hline & & & Amozeshgah & .04794 & .13290 & .937 \\
\hline
\end{tabular}


In addition to studying Iranian students' perceptions of their English teachers' power based on French \& Raven's (1959) framework of relational power which were measured by TPUS (2007), this research studied and compared students' perception of other kinds of teachers' power. Thus, some common and different types of teacher's power were reported in both observations and interviews.

First, all EFL students - in high schools, universities, and English language institutes -insisted on their teachers' friendly power and added that they saw their teachers as their friend rather than their professor. Teachers' friendly power had led to opportunities that teachers could consult with students and so provided necessary guidance for not only students' problems in learning English, but also in their personal life.

Contrary to teacher's friendly power, Iranian students in all three academic contexts- however more in high schools and universities, and less in English language institutes, complained about their teachers' bias power. They stated that their English teacher supported specific number of students while ignored others with the same abilities.

Also, most of the students in universities and English Language institutes and a few students of high schools welcomed their teacher's psychological power. The students described teachers' psychological power as their close attention to both students' educational and also emotional conditions. Teacher's guessing ability of students' problems in different field of learning and representing the best solution according to learners' characteristics like extrovert versus introvert students were among the other evidences of teacher's psychological power.

Regarding commonalities in high schools and English language institute, -but not much in the universities-, the students attributed time management to one of the important kinds of the teachers' power. The students said that there was never waste of time in their classes and their teacher controlled whatever was taught and learned based on specific lesson plans for each session.

Also in both universities and English language institutes, the students emphasized on their teachers' tolerance or patience power. For instance, teachers' tolerance power of noisy students and at the same time control of the class were described as evidence of teachers' tolerance power. Also the teachers' use of various techniques to transfer the lesson to weak students and lack of their anger or tiredness highlighted teacher's tolerance power. Additionally, students in universities and English language institutes appreciated their teachers' cooperative power that led teacher to cooperate with students in making educational decisions, doing projects, and at last increasing the students' self-esteem through cooperation. Such teachers' cooperative power in universities and English language students was highlighted with use of Internet technology. This refers to sending and receiving mails between teachers and students; creating lesson group in Facebook, Telegram, and Viber by teachers and students' responding to online exams. The other feature of teachers' power in universities and English language institutes was reported as teachers' critical thinking power. The students expressed teachers' critical thinking power as asking why questions, wanting appropriate reasons and evidence for students' responses, and etc.

Regardless of most useful kinds of teacher's power in high schools, students pointed to teachers' threatening power which they were afraid of. A few of these teachers with threatening power even sometimes used offensive language in the class that just resulted in students' high level of anxiety and leaving the English class.

Concerning universities, the students referred to their teacher's modesty or humility power and added that this feature distinguished their English teacher from some other professors. The students explained their classroom atmosphere as where teacher underestimates his/her claims in order to teach certain disciplines and also as where mutual respect exists between teacher and students and students' opposing - but true ideas- are welcomed by teacher.

Eventually with regard to English language institutes, the students admired their teachers' flexibility power. They said that their teacher tries to adjust himself with students' conditions and so doesn't force his own ideas or fixed syllabuses on students. Also, students insisted that teachers in English language institutes speak loudly, clearly, and change the tone of their voice in order to attract students' attention and make the classroom more exciting and fun.

\section{Discussion}

This study aimed to find about Iranian high school, university, and English language institute students' perceptions of their English teachers' power based on their responses to TPUS (2007) which was based on French \& Raven' (1959) power bases. For this purpose, the researcher used Teacher Power Use Scale (TPUS, Schrodt, Witt, \& Turman (2007). Later, the research looked for the same students' perceptions of other kinds of teachers' power except what were measured by TPUS (2007). The researcher found some similarities and 
differences in students' perceptions of teachers' power among high schools, universities and English language institutes. Statistical findings reported students' perceptions of teachers' coercive power in universities as the second factor which had greatest mean in schools. Further, the interviews showed similar results. University students who were weak in English attributed their weakness to their English teachers' coercive power through punishment, misbehavior, and contempt in high school. It is interesting to remind here that researcher also confirmed the teacher's coercive power during class observations in high schools and was worried about this in future success of students.

Moreover, the interviews announced teachers' tolerance or patience power and cooperative power in both universities and English language institutes which did not exist enough for high school teachers. In fact, considering the ages of leaners in high schools and the need to make their personality, and self-esteem in that age, the need to teachers' patience and cooperative power seem doubled and even more.

Finally, teacher's flexibility power that was famous in English language institutes can be used reasonably in both universities and high language schools in order to make learning easier and teach flexibility to students in their life.

In conclusion, due to the importance of leaning English as an international language, the researcher focused on students' perception of English teachers' power. Unfortunately, there are still some teachers who do not have enough knowledge of different theories and choices about teacher's power (Webb, 2002). These teachers are interested to follow the traditional and dictatorial teacher's power and impose their ideas on students.

Thus, this research tried to introduce students' perceptions of other kinds of teachers' power besides what were proposed by French \& Raven's (1959) power typology. Also, this study suggests appropriate use of teachers' power in order to improve both teaching and learning process, particularly facilitate teaching English to foreign language learners.

For further research, it is desirable to study students' perceptions of French and Raven's relational power (1959) and also of other kinds of teachers' power - presented in this research-between male versus female students, and young versus adult students. Also, it is suggested to study and compare students' satisfaction of teachers' power among high school, university, and English language institute.

\section{Acknowledgements}

I wish to express my deepest gratitude to Dr. Assadi, for his kind and invaluable supervision and insightful comments. He encouraged me in different stages of my postgraduate studies and writing this article. I thank him from the depth of my heart.

Last, but not least, I am particularly indebted to my family for their unfailing encouragement, and devotion.

\section{References}

Barkhuizen, G. P. (1998). Discovering learners' perceptions of ESL classroom teaching/learning activities in South African context. TESOL Quarterly, 32(1), 23-40. http://dx.doi.org/10.2307/3587903

Chesler, M. A., \& Franklin, J. (1968). Interracial and intergenerational conflict in secondary schools. Paper presented at the Annual Meeting of the American Sociological Association, Boston, Massachusetts, August.

Chesler, M. A., \& Lohman, J. E. (1971). Changing schools through student advocacy. In R. Schmuck \& M. Miles (Eds.), Organization development in schools (pp. 185-212). Palo Alto, Calif.: National Press Books.

Dörnyei, Z. (2007). Research methods in applied linguistics: Quantitative, qualitative, and mixed methodologies. Oxford: Oxford University Press.

Fairclough, N. (1989). Language and Power. London: Longman.

Fisch, L. (1992). Power in College Teaching. Teaching Excellence.

French, J. R. P., \& Raven, B. (1959). The bases of social power. In D. Cartwright (Ed.), Studies in social power (pp. 150-167). Ann Arbor: University of Michigan Press.

French, J. R. P., \& Raven, B. H. (1968). Group Dynamics: Research and Theory, chapter Bases of social power.

Harjunen, E. (2009). How do teachers view their own pedagogical authority? Teachers and Teaching, 15, 109-129. http://dx.doi.org/10.1080/13540600802661345.

Hatch, E. (1992). Discourse and language education. Cambridge: Cambridge University Press.

Huebner, E. S., Gilman, R., Reschly, A. L., \& Hall, R. (2009). Positive schools. In S. J. Lopez \& C. R. Snyder (Eds.), Oxford handbook of positive psychology (2nd ed.) (pp. 561-568). Oxford: Oxford University Press. 
http://dx.doi.org/10.1093/oxfordhb/9780195187243.013.0053

Hurt, H. T., Scott, M. D., \& M. D., \& McCroskey, J. C. (1978). Communication in the classroom. Reading, MA: Addison-Wesley.

Jackman, W. M. (2014). Assessing the Practicality and Relevance of Adventist Educational Philosophy in a Contemporary Education Paradigm. Journal of Research on Christian Education, 23(3), 307-325. http://dx.doi.org/10.1080/10656219.2014.966874

Johnson, G. (1997). Reframing teacher education and teaching: from personalism to post-personalism. Teacher and Teacher Education, 13(8), 815-829. http://dx.doi.org/10.1016/S0742-051X(97)00028-0

Johnson-Bailey, J., \& Cervero, R. M. (1997). Beyond facilitation in adult education: Power dynamics in teaching and learning practices.

Kearney, P., Plax, T. G. Richmond, V. P., \& McCroskey, J. C. (1984). Power in the classroom IV: Alternatives to discipline. In R. N. Bostrom (Ed.), Communication Year Book (vol. 8, pp. 724-746). Beverly Hills, CA: Sage. http://dx.doi.org/10.1080/23808985.1984.11678598

Kumaravadivelu, B. (1991). Language learning tasks: Teacher intention and learner interpretation. ELT Journal, 45(2), 98-102. http://dx.doi.org/10.1093/elt/45.2.98

Macbeath, J., \& Mortimore, P. (2001). Improving school effectiveness. Philadelphia: Open University Press.

Maxcy, S. J. (1991). Educational Leadership: a critical pragmatic perspective. New York: Bergin \& Garvey.

McCroskey, J. C., \& Richmond, V. P. (1983). Power in the classroom I: Teacher and student perceptions. Communication Education, 32(2), 175-184. http://dx.doi.org/10.1080/03634528309378527

Metz, M. H. (1978). Classroom and corridors: The crisis of authority in desegregated secondary schools. Berkeley: University of California Press.

Miles, M. B. (1967). Some Properties of Schools as Social Systems. Age Grade Placement, 31.

Peters, R. S. (1966). Authority, responsibility, and education. New York: Atherton.

Quicke, J. (1999). A Curriculum for Life: Schools For a Democratic Learning Society. Buckingham: Open University Press.

Raywid, M. A. (1995). A teacher's awesome power. To become a teacher: Making a difference in children's lives, 78-85.

Richmond, V. P., \& McCroskey, J. C. (1984). Power in the classroom II: Power and learning. Communication Education, 33(2). http://dx.doi.org/10.1080/03634528409384729

Schrodt, P., Witt, P. L., \& Turman, P. D. (2007). Reconsidering the measurement of teacher power use in the college classroom. Communication Education, 56, 308-332. http://dx.doi.org/10.1080/03634520701256062

Schrodt, P., Witt, P. L., Myers, S. A., Turman, P. D., Barton, M. H., \& Jernberg, K. A. (2008). Learner empowerment and teacher evaluations as functions of teacher power use in the college classroom. Communication Education, 57(2), 180-200. http://dx.doi.org/10.1080/03634520701840303

Smith, B., \& Hains, B. (2012). Examining administrators' disciplinary philosophy: A conceptual model. Education Administration Quarterly, 48(548), 548-576. http://dx.doi.org/10.1177/0013161X12441363

Uusiautti, S., \& Määttä, K. (2012). Can teachers teach children how to be moral? British Journal of Education, Society \& Behavioural Science, 2(3), 260-270.

Van Dijk, T. A. (2001). 18 Critical discourse analysis. The handbook of discourse analysis, 349-371.

Van Manen, M. (1991). The tact of teaching: The meaning of pedagogical thoughtfulness. New York: Suny Press.

Walls, R. T., Sperling, R. A., \& Weber, K. D. (2001). Autobiographical memory of school. The Journal of Educational Research, 95(23), 116-127. http://dx.doi.org/10.1080/00220670109596580

Webb, P. T. (2002). Teacher power: The exercise of professional autonomy in an era of strict accountability. Teacher Development, 6(1), 47-62. http://dx.doi.org/10.1080/13664530200200156

Welman, J. C., \& Kruger, S. J. (1999). Research methodology for the business and administrative sciences. Johannesburg, South Africa: International Thompson.

Wodak, R., \& Meyer, M. (Eds.). (2015). Methods of critical discourse studies. Beverly Hills, CA: Sage. 


\section{Copyrights}

Copyright for this article is retained by the author(s), with first publication rights granted to the journal.

This is an open-access article distributed under the terms and conditions of the Creative Commons Attribution license (http://creativecommons.org/licenses/by/4.0/). 